\title{
Changes in Community Attitudes and Their Participation in the Community-Based Water Supply and Sanitation Program (PAMSIMAS) in Gowa Regency
}

\author{
Muhammad Arsyam ${ }^{1}$, Nurfatimah Nurfatimah ${ }^{2}$, Ibnu Hajar $S^{3}$, Andi Jusmiana ${ }^{4}$, Zulkifli \\ Makmur ${ }^{5}$, Syamsul Alam ${ }^{6}$ \\ ${ }^{1}$ Sekolah Tinggi Agama Islam (STAI) Darul Dakwah Wal-Irsyad (DDI) Kota Makassar, \\ Indonesia \\ Email: arsyam0505@gmail.com \\ ${ }^{2}$ Universitas Islam Negeri (UIN) Alauddin Makassar, Indonesia \\ Email: nurfatimah.nurfatimah91@gmail.com \\ ${ }^{3}$ Sekolah Tinggi Agama Islam (STAI) Darul Dakwah Wal-Irsyad (DDI) Kota Makassar, \\ Indonesia \\ Email: dewaibnuhajar@gmail.com \\ ${ }^{4}$ Universitas Pejuang Republik Indonesia, Makassar, Indonesia \\ Email: andijusmiana@gmail.com \\ ${ }^{5}$ Sekolah Tinggi Agama Islam (STAI) Darul Dakwah Wal-Irsyad (DDI) Kota Makassar, \\ Indonesia \\ Email: zulkifli.makmur@mail.ugm.ac.id \\ ${ }^{6}$ Universitas Islam Negeri (UIN) Alauddin Makassar, Indonesia \\ Email: syamsul.uin05@gmail.com
}

\begin{abstract}
The government has made efforts to create a clean and healthy environment by developing easy and sustainable access to drinking water and sanitation. The community was actively involved in this development program in the form of building indoor wells, implementing Clean and Healthy Behavior (PHBS), and establishing a committee to maintain and manage the facilities as an integrated program sustainable towards universal access (100-0100). The central government, represented by the Ministry of PUPR, has run the CommunityBased Water Supply and Sanitation (PAMSIMAS) program. This research was conducted using a qualitative approach. The content analysis was done through in-depth interviews, documentary review, and observation. The subjects of this study were regency work unit, partnership committee, district coordinator (DC), co-DC, data entry and administration officer, community facilitator, community self-help group, implementing unit, drinking water management facility management group, Belabori Village government, the village head, sanitarian, and the waterusing community in Belabori Village, Parangloe District, Gowa Regency, totaling 25 people. The data were collected by questionnaires. The results showed that the processes of planning, implementing, and maintaining the PAMSIMAS program in Belabori Village were carried out by the community through deliberations. Besides, there had been a change in community behavior. The community's awareness of healthy and clean living and their participation level in overseeing the program at all the stages can be seen from the maintenance of the PAMSIMAS program since it was launched in 2017 until 2020. Therefore, it can be concluded that the PAMSIMAS program has a positive impact on the community: the community can easily access clean water at $\mathrm{Rp} 3.000 / \mathrm{m}^{3}$ and stop doing open defecation. Changes in the community behavior and attitudes and their participation level as a form of their sense of belonging to the facilities built in Gowa Regency have occurred.
\end{abstract}

Keywords: Change; Attitude; Participation; PAMSIMAS

\section{Introduction}

Following Presidential Regulation No. 18 of 2020 concerning the Mandate of the RPJMN 20202024, the Indonesian government has targetted to provide safe drinking water and proper sanitation services for all Indonesians [1]. Nationally, until the end of 2018, safe drinking water and basic sanitation, respectively, were only available for $88 \%$ and $75 \%$ of the total population of Indonesia [2-3]. Those underserved are those with low-income in rural and suburban areas that are among the most vulnerable groups who lack access to safe drinking water and proper sanitation [4-5]. 
The PAMSIMAS I and II programs implemented from 2008 to 2015 have succeeded in increasing the number of rural and suburban poor who can access drinking water and sanitation services, as well as increasing the value and behavior of clean and healthy living through community empowerment [6]. This community empowerment approach has been able to increase community participation as a strategic partner of the local and central government in providing and improving the quality of water and sanitation services [7].

The existence of the PAMSIMAS III program was implemented in 2016-2020 as the continuation of the PAMSIMAS I and II programs. It was an instrument for implementing two national agendas that aimed to increase the number of the population who can access to proper and sustainable drinking water and sanitation services, by sticking to the concept of meeting the target " $100 \%$ of the population have the access to drinking water and sanitation", with the principle of Community-Based Total Sanitation [8].

The next objectives of the PAMSISMAS program were to increase the number of under-served citizens, including low-income people in rural areas who are less able to access drinking water and sanitation services and to improve the application of clean and healthy living values and behavior. Furthermore, the next goal was to achieve the target of access to drinking water and sanitation by 2030 in the water and sanitation sector, through a community-based development approach.

Based on Law No. 23 of 2014 concerning the Regional Government, the basic public services, namely drinking water and sanitation services, have become the obligations of the Regional Government. To support the capacity of regional governments in providing drinking water and sanitation services that meet the Minimum Service Standards (SPM), the PAMSIMAS Program plays a role in providing financial support, both for physical investment in facilities and infrastructure and for non-physical investment in management, technical support, and capacity development.

In managing the PAMSIMAS Program, the community is more dominant, while the government only acts as a facilitator. All activities starting from program planning to its implementation are carried out by the community. Community participation in water management is to make use of the water resources they have, while also preserving them [9]. Water is one of the basic human needs and is very necessary for improving the quality of human life and economic growth in a region. The central government and the provincial government are responsible and guaranteeing the implementation of public services, including clean water services [10].

Therefore, based on the description above, this research would focus on changes in community attitudes, their participation in PAMSMAS program activities, and the impacts of the program.

\section{Research Method}

Using the descriptive-qualitative research method [11], the researchers conducted qualitative observations of an object that would be examined based on descriptive data, in the form of written words or oral information from people and observed behaviors. Also, in this descriptive study, they noted, analyzed, and interpreted the conditions based on the reality.

Accuracy in this study was specific to the source of the data obtained, namely Population, which was 82 villages spread across 16 districts in Gowa Regency that received the PAMSIMAS Program from 2008-2019. Considering that the population in this study was quite large, the researchers conducted a purposive sampling in order to obtain truly representative samples [12], one of which was Belabori Village, Parangloe District, Gowa Regency, in the 2017 Pamsimas program, totaling 25 people. Furthermore, in terms of data collection techniques, this study did observations, interviews, and questionnaires. In the data analysis process, the researchers performed data reduction, data presentation, and data verification. 


\section{Findings and Discussion}

\subsection{Overview of Research Locations}

The target villages of the PAMSIMAS program in Gowa Regency were spread in 82 villages and 16 districts from 2008 to 2019 as follows; Tompobulu District consisting of 7 villages, Biringbulu District consisting of 11 villages, Bontolempangan District consisting of 8 villages, Tinggimoncong District consisting of 3 villages, Tombolo Pao District consisting of 9 villages, Bungaya District consisting of 7 villages, Manuju District consisting of 6 villages, Parigi District consisting of 5 villages, Bontonompo District consisting of 7 villages, Bontonompo Selatan District consisting of 3 villages, Bajen District consisting of 3 villages, Bajen Barat District consisting of 1 village, Pallangga District consisting of 2 villages, Bontomarannu District consisting of 1 village, Pattallassang District consisting of 4 villages, and, the last, Parangloe District consisting of 5 villages [13].

The 16 sub-districts above were areas proposed by the regent of Gowa after the selection process by the Gowa Regency-level Partnership Committee Team. The researchers considered that these villages were the right target. Overall, these villages had adequate sources of raw water. However, there were still villages that had not been well managed thus having not benefited the local community [14].

Based on observations, the conditions of the villages before the implementation of the PAMSIMAS program could be known. Villagers, in general, have difficulties in getting clean water to meet their daily needs, including for consumption. The PAMSIMAS program, in its implementation, must consider some components, namely Quality, Quantity, Continuity, and Affordability. The water to be consumed must have good quality, be available in sufficient quantity, come from sustainable sources, and be at an affordable price for the local community. Therefore, the authors' research site or location, namely in Belabori Village, Parangloe District, Gowa Regency, had fulfilled all the four components.

\subsection{Changes in Village Community Behavior and Participation}

The PAMSIMAS program has been implemented with a community-based approach through community involvement (women and men, rich and poor, etc.) and a responsive approach to community needs. Both approaches have been carried out through the process of community empowerment to foster community initiatives and active participation in deciding, planning, preparing, implementing, operating, and maintaining the facilities that have been built, as well as continuing activities to improve health status in the community, including in the school environment [15].

The scope of the PAMSIMAS program includes five program components: 1) Community empowerment and regional and village institutional development; 2) Improvement of hygienic behavior and sanitation services; 3) Provision of public drinking water and sanitation facilities; 4) Incentive Grants; and 5) Technical and management support for program implementation.

Therefore, according to Ir. Herlina Machmud, M.T., in principle, in terms of managing the PAMSIMAS program, the community is more dominant and the government only acts as a facilitator. All activities ranging from program planning to implementation are carried out by the community. Community participation in water management is to make use of the water resources they have, while also preserving them.

Thus, the community in the village must be really active in all stages of the program activities. The same thing was also conveyed by Wahida Susilawati, SKM., suggested that to realize the objectives of the PAMSIMAS program in the villages, the most important key indicators of the 
PAMSIMAS program performance are, one, the achievement of at least 70\%: the regency government has a regional planning document for drinking water and sanitation to support adoption and mainstreaming of the PAMSIMAS approach and achievement of regional water and sanitation development targets; secondly, attainment of at least 60\%: the regency government has increased spending on drinking water and sanitation in the context of maintaining current water and sanitation service systems and achieving universal access to drinking water and sanitation.

Furthermore, the strategies, approaches, and principles of the PAMSIMAS program are to create a strategic environment that supports the achievement of program objectives: the community is expected to be willing to apply the behaviors and practices of clean and healthy living behavior (PHBS). The next hope is that the community will get sustainable access to safe drinking water and proper sanitation services, and can participate in using, maintaining, and managing services independently, effectively, and sustainably.

In line with the principles of the community-based development approach, it is expected that the community will have a full role in deciding, planning, implementing, operating, and maintaining existing water and sanitation facilities and infrastructure independently [16].

From the results of the above description, the real goal is to change the behavior of people in the village towards clean and healthy living behavior (PHBS) and increase access to basic sanitation at all levels of society, especially for women and children. This will support and complement the components of the construction of drinking water and environmental sanitation facilities and infrastructure [17]. At the implementation of PHBS promotion at the village level, it should be carried out through families, local/village institutions, public facilities such as schools, places of worship, and through printed and electronic mass media [18]..

\subsection{Effects of the PAMSIMAS Program on Society}

This study took one sample, namely the village that had been designated as the village of PAMSISMAS in 2017 in the District of Parangloe, Gowa Regency. Belabori Village was in need of drinking water and proper sanitation to meet the needs of daily life. Therefore, the authors in this study distributed questionnaires to each family head in Belabori Village, namely users of the PAMSIMAS drinking water program and those who had not enjoyed PAMSIMAS water, for the aim of comparing their answers.

Clear information was obtained through community responses, as illustrated in the following table:

Table 1. Response to the Existence of the 2017 PAMSIMAS Program

\begin{tabular}{|c|l|c|c|}
\hline No. & \multicolumn{1}{|c|}{ Response } & \multicolumn{1}{|c|}{$\begin{array}{c}\text { Number of } \\
\text { Respondents }\end{array}$} & Percentage \\
\hline 1 & Strongly agree & 15 & 60.00 \\
\hline 2 & Agree & 9 & 36.00 \\
\hline 3 & Disagree & 1 & 4.00 \\
\hline 4 & Strongly disagree & 0 & .00 \\
\hline \multicolumn{2}{|c|}{ Total } & 25 & $100 \%$ \\
\hline
\end{tabular}

The tabulation analysis of the data above shows that 15 respondents stated strongly agree with the 2017 PAMSIMAS Program, 9 respondents stated agreed, 1 respondent stated disagreed, and no one stated strongly disagree. Therefore, from this data, it can be concluded that the people of Belabori Village, Parangloe Subdistrict, Gowa Regency welcomed with great enthusiasm the existence of the PAMSIMAS program, as evidenced by the high percentage of answers expressing agreement, which is $60.00 \%$ giving answers strongly agree and $36.00 \%$ give answers agree. Very 
small percentage of people rejected this program; only $4.00 \%$ gave answers disagree and $0.00 \%$ gave answers strongly disagree.

Changes in community attitudes towards the implementation of the PAMSIMAS program in Belabori Village are very good, as seen in the following table:

Table 2. Changes in Community Attitudes Towards the PAMSIMAS Program

\begin{tabular}{|c|l|c|c|}
\hline No. & \multicolumn{1}{|c|}{ Response } & $\begin{array}{c}\text { Number of } \\
\text { Respondents }\end{array}$ & Percentage \\
\hline 1 & Very good & 17 & 68.00 \\
\hline 2 & Good & 6 & 24.00 \\
\hline 3 & Fair & 2 & 8.00 \\
\hline 4 & Poor Total & 0 & .00 \\
\hline \multicolumn{2}{|c|}{ T } & 25 & $100 \%$ \\
\hline
\end{tabular}

The results of the analysis of the table above show that 17 respondents changed attitudes towards the PAMSIMAS program activities in Belabori Village categorized as "very good", 6 respondents categorized as "good", 2 respondents categorized as "fair", and no respondents categorized as "poor". Thus, from this data, it could be concluded that the people of Belabori Village, Parangloe District, Gowa Regency welcomed very well the existence of the PAMSIMAS program, as evidenced by the high percentage of community response, namely $68.00 \%$ assessed "very good", $24.00 \%$ assessed "good", and $8.00 \%$ assessed "fair". This means that there were only a few people changed their attitudes towards this program, and $0.00 \%$ assessed "poor".

Furthermore, the level of community participation in the implementation of the PAMSIMAS program in Belabori Village was very high. This can be seen in the following table:

Table 3. The Level of Community Participation in the Implementation of the PAMSIMAS

\begin{tabular}{|c|l|c|c|}
\hline No. & \multicolumn{1}{|c|}{ Response } & $\begin{array}{c}\text { Number of } \\
\text { Respondents }\end{array}$ & Percentage \\
\hline 1 & Very high & 13 & 52.00 \\
\hline 2 & High & 7 & 28.00 \\
\hline 3 & Somewhat high & 3 & 12.00 \\
\hline 4 & Low & 1 & 4.00 \\
\hline 5 & Very low & 1 & 4.00 \\
\hline \multicolumn{2}{|r|}{ Total } & 25 & $100 \%$ \\
\hline
\end{tabular}

From the results of the analysis of the table above, in terms of participation in the PAMSIMAS program activities, it is known that 13 respondents the Belabori Village were categorized as very high, 7 respondents were categorized as high, 3 respondents were categorized as quite high, and 1 respondent was categorized as low, and 1 respondent was categorized as very low. Thus, from this data, it can be concluded that the level of community participation in Belabori Village, Parangloe Subdistrict, Gowa Regency on the existence of the PAMSIMAS program was proven to be very high based on the percentage of community responses, namely $52.00 \%$ answered very high, $28.00 \%$ answered high, $12.00 \%$ answered somewhat high, $4 \%$ answered low, and $4 \%$ answered very low. Thus, a very low percentage of people did not participate in this program.

In addition to PDAMs, the PAMSIMAS Program has become a barometer of the feasibility of drinking water and proper sanitation services in rural communities. This can be seen by the good maintenance of facilities and infrastructure that have been built through the PAMSIMAS program [19]. Thus, the facility management agency in the village, namely the Belabori Village Water Supply and Sanitation Facility Management Group (KPSPAMS), has a very large role related to the sustainability of the program at the community level. In the aspect of maintenance, in Belabori 
Village, there are contributions in the form of money aimed at operational costs and maintenance of facilities constructed so that buildings can last a long time.

This article shows that the existence of the PAMSIMAS program for the community is very instrumental in overseeing activities, starting from the initial planning to its sustainability. Based on observations, the distribution of water using pipes and using a house connection system (SR) can serve the community according to the target beneficiaries, as contained in the Community Work Plan (RKM). Compared to Chaerunnissa's research, in the planning stage, community participation in the PAMSIMAS Program is in the form of thoughts and offering more suggestions and criticisms. At the Implementation Stage of the development, the community participates more in the form of labor, because many people have low incomes [20].

Finally, this article states that changes in behavior and level of community participation in the PAMSIMAS program in Gowa Regency, specifically in Belabori Village, shows that the existence of the PAMSIMAS program for the community, while monthly fees are still applied, still has a positive impact related to easy access to water at a price of $\pm \mathrm{Rp} 3.000 / \mathrm{m}^{3}$ that has been mutually agreed upon, based on the system of application of fees. With the application of the contribution system (monthly fee), the programs of providing the needs for clean water and stopping the community from doing open defecation as a form of PHBS behavior [21-22] have been implemented. Thus, changes in community behavior, attitudes, and participation have been implemented in the forms of their sense of belonging to the facilities built in Gowa Regency.

\section{Conclusions}

This article concludes that, first, the community is at a high level of agreement on the existence of the 2017 PAMSIMAS program in Gowa Regency, changes in community behavior are very good, and the level of community participation is very high. Secondly, the existence of the PAMSIMAS program for the community has a positive impact related to the easy access to water at a price of $\pm \mathrm{Rp} 3.000 / \mathrm{m}^{3}$ in order to meet the needs for clean water, stopping the community from doing open defecation, as a form of PHBS behavior, so that changes in community behavior, attitudes, and participation are built as a form of their sense of belonging to the facilities built in Gowa Regency.

\section{References}

[1] S. M. Nurjaya, S. Lambali, M. Yunus, \& M. T. Abdullah 2020 The Mobilization of Shared Principles in The Community Based Drinking Water Supply and Sanitation (Pamsimas) in The Perspective of the Collaborative Governance Regim (Cgr) in Maros Regency. European Journal of Research in Social Sciences, 82

[2] W. Arief, \& P. A. Arif 2019 Sanitation, Drinking Water Access and Diarrhea in Indonesia Russian Journal of Agricultural and Socio-Economic Sciences, 851

[3] V. I. W. Nalle, M. D. Syaputri, \& P. F. Haryono 2019 Issues in Acceleration of Establishment of Domestic Wastewater Regulation in Indonesia Mediterranean Journal of Social Sciences, $10684-84$

[4] B. van Bavel, F. Larkan, J. E. Nally, \& A. Purwati 2019 An Interdisciplinary Study of Leptospirosis Surveillance Systems in Three Regencies of East Java, Indonesia In Law, Public Policies and Complex Systems: Networks in Action. Springer, Cham. 89-112

[5] A. Rahman, S. Iwasaki, S. A. Sutton, \& A. Sakurai 2019 Urban Water Management Issues and Challenges After the 2004 Indian Ocean Tsunami Recovery: Lessons Learned from Banda Aceh City, Indonesia In Urban Drought. Springer, Singapore. 399-412

[6] J. Cook, D. Fuente, M. Matichich, \& D. Whittington 2020 A Global Assessment of Nontariff Customer Assistance Programs in Water Supply and Sanitation In Development Studies in 
Regional Science. Springer, Singapore. 315-371

[7] E. Azmanajaya, C. A. Paulus, \& N. Paranoan 2020 The Sustainability index of the provision of clean water treatment plants (IPAB) in supporting SDG 2030 programs for the availability and management of sustainable clean water in Soppeng Regency, South Sulawesi Province, Indonesia In IOP Conf. Series: Journal of Physics: Conf. Series, 1464

[8] D. Herlinda, \& B. C. Utami 2020 Water Supply and Sanitation: Problems on Community Empowerment Based Program in Indragiri Hulu, Indonesia E\&ES, 4691012030

[9] A. Susilo, Y. Vidyattama, \& D. A. P. E. Wishanti 2020 Water and Sanitation Program in Decentralised Eastern Indonesia: The Roles of Community and Social Dynamics Australasian Journal of Regional Studies, 261

[10] K. L. Bria, \& M. Raharjo 2020 Evaluation Of Total Sanitation Program Based On Open Defecation Free Pilar Community In Belu District International Journal of Health, Education \& Social (IJHES), 34 8-18

[11] D. J. Hunter, \& D. Howes 2020 Defining Exploratory-Descriptive Qualitative (EDQ) research and considering its application to healthcare GSTF Journal of Nursing and Health Care (JNHC), 41

[12] H. Kyngäs 2020 Qualitative Research and Content Analysis In The Application of Content Analysis in Nursing Science Research. Springer, Cham. 3-11

[13] Hajar 14 Mei 2020 Data entry and administration officer, Pamsimas Kabupaten Gowa Sumber Data Kantor Pamsimas.

[14] A. M. Hatta 14 Mei 2020 Co-DC Pamsimas Kabupaten Gowa Sumber Data Kantor Pamsimas.

[15] J. La Fua, R. U. Nurlila, F. Gunawan, \& I. S. Wekke 2018 Islamic education on formation of environmental awareness in Indonesian Islamic Boarding Schools In IOP Conference Series: Earth and Environmental Science. IOP Publishing. 1561012035

[16] L. Alfita, A. L. Kadiyono, P. T. Nguyen, W. Firdaus, \& I. S. Wekke 2019 Educating the External Conditions in the Educational and Cultural Environment International Journal of Higher Education, 88

[17] S. Kuraedah, F. Gunawan, I. S. Wekke, \& B. Hamuddin 2018 Learning environment construction in Islamic Higher Education: Connecting the puzzles of ideas In IOP Conference Series: Earth and Environmental Science. IOP Publishing. 1751012107

[18] M. Idris, E. Willya, I. S. Wekke, \& S. Mokodenseho 2020 Peace Resolution in Education and Application on Information and Communication Technologhy International Journal of Advanced Science and Technology. 296 3349-3358

[19] M. Muniah, S. Soemarno, \& N. Harahab 2019 The Role of Community Participation In Sustainability Water Resources Management in Malang District The Indonesian Green Technology Journal, 82

[20] C. Chaerunnissa 2015 Partisipasi Masyarakat dalam Program Penyediaan Air Minum dan Sanitasi Berbasis Masyarakat (Pamsimas) di Kabupaten Brebes (Studi Kasus Desa Legok dan Desa Tambakserang Kecamatan Bantarkawung) Politika: Jurnal Ilmu Politik, 5 2 99-113

[21] P. S. Komala, A. Nur, \& S. Septanisa 2020 Real demand survey of the water supply system in Padang city. In AIP Conference Proceedings. AIP Publishing LLC. 22301040005

[22] I. Cunningham, J. Willetts, K. Winterford, \& T. Foster 2019 Participation and Power Dynamics Between International Non-Governmental Organisations and Local Partners: A Rural Water Case Study in Indonesia Water Alternatives-An Interdisciplinary Journal on Water Politics And Development. 